\title{
Study of dermatoses in kidney transplant patients
}

\author{
Estudo das dermatoses em pacientes transplantados renais
}

\author{
Alexandre Moretti de Lima ${ }^{1}$ \\ Eugênio Galdino de Mendonça Reis Filho ${ }^{3}$ \\ Carmelia Matos Santiago Reis ${ }^{4}$
}

\author{
Sheila Pereira da Rocha ${ }^{2}$ \\ Danglades Resende Macedo Eid ${ }^{2}$
}

DOI = Digital Object Indentifier $=$ http://dx.doi.org/10.1590/abd1806-4841.20131859

\begin{abstract}
BACKGROUND: The increasing in the number of kidney transplant recipients has favored, more frequently than before, the emergence of dermatoses and warranted their study through subsequent publications. OвJестIVES: to evaluate the frequency of dermatoses in kidney transplant recipients. METHODS: kidney transplant recipients with suspected dermatoses between March 1st 2009 and June 30th 2010. RESULTs: 53 patients (28 males and 25 females), aged between 22 and 69 (mean age $=45$ years) were evaluated. Most of them came from the cities of Ceilândia, Samambaia and São Sebastião/DF, and had already been transplanted for 5 to 10 years before $(37.7 \%) ; 83 \%$ were prednisone-treated. The most prevalent dermatoses were of fungal $(45.3 \%)$ and viral $(39.6 \%)$ etiologies. Among the non-melanoma malignant neoplasms, the basal cell carcinoma prevailed (six cases), in spite of the low incidence. Concerning fungal dermatoses, 12 cases of onychomycosis, five of pityriasis versicolor and four of pityrosporum folliculitis were reported. For diagnosis, in most cases $(64.2 \%)$, laboratory examinations (mycological and histopathological) were performed. CONCLUsION: cutaneous manifestations in kidney transplant recipients are generally secondary to immunosuppression. The infectious dermatoses, especially those of fungal origin, are frequently found in kidney transplant recipients and their occurrence increases progressively according to the time elapsed from the transplantation, which makes follow-up important.

Keywords: Immunosuppression; Kidney transplantation; Onychomycosis; Prednisone
\end{abstract}

Resumo: FUNDAMENTOS: o crescente aumento do número dos transplantados renais tem favorecido o aparecimento mais frequente das dermatoses e permitido o estudo em sucessivos trabalhos. OBJETIVos: avaliar a frequência das dermatoses em pacientes transplantados renais. MÉTODos: captação de pacientes transplantados renais durante o período de $1^{\circ}$ de março de 2009 a 30 de junho de 2010 com suspeita de dermatoses. RESULTADOS: foram avaliados 53 pacientes (28 homens e 25 mulheres), entre 22 e 69 anos (com uma média de 45 anos), a maioria procedente de Ceilândia, Samambaia e São Sebastião/DF, entre 5 e 10 anos de transplante renal (37,7\%), 83\% em uso de prednisona. As dermatoses mais prevalentes foram as de etiologia fúngica $(45,3 \%)$ e viral $(39,6 \%)$. Das neoplasias malignas não-melanoma, apesar da baixa incidência, predominou o carcinoma basocelular (seis casos). Com relação às dermatoses de origem fúngica, ocorreram 12 casos de onicomicoses, cinco casos de pitiríase versicolor e quatro casos de foliculite pitirospórica. Para realização do diagnóstico, na maioria dos casos $(64,2 \%)$, foi utilizado os exames laboratoriais ( micológicos e histopatológicos). ConCLUSÃo: as manifestações cutâneas em pacientes transplantados renais são geralmente secundárias à imunossupressão. As dermatoses infecciosas, principalmente as de etiologia fúngica, são frequentes em pacientes transplantados renais, e sua ocorrência aumenta progressivamente, conforme o tempo transcorrido, a partir do transplante, sendo importante o acompanhamento.

Palavras-chave: Imunossupressão; Onicomicose; Prednisona; Transplante de rim

\footnotetext{
Received on 07.05.2012.

Approved by the Advisory Board and accepted for publication on 27.08.2012

* Work performed at the Hospital Escola - Hospital Regional da Asa Norte (HRAN) - Brasília (DF), Brasil

Financial support: Research Project funded by ESCS/FEPECS.

Conflict of interests: none.

Specialist in Medical Clinic and Dermatology - Professor Assistant in Dermatology at the Federal University of Mato Grosso do Sul (UFMS) - Campo Grande (MS), Brazil.

Specialist in General Medicine and Dermatology. Private Clinic - Brasília (DF), Brazil.

Specialist in Dermatology. Private Clinic- Brasília (DF), Brazil.

PhD in Medicine (Dermatology) at the Federal University of Rio de Janeiro - Supervisor of Medical Internship in Dermatology at a Teaching Hospital Hospital Regional da Asa Norte (HRAN) - Brasília (DF), Brazil.

(C2013 by Anais Brasileiros de Dermatologia
} 


\section{INTRODUCTION}

The first description of kidney transplant in the medical literature occurred in 1902 by the Medical Society of Vienna and was held by the Polish surgeon Emerich Ullmann. It was a kidney self-transplant in a dog's neck. ${ }^{1}$ In the same year, Dr Ullman performed another experiment, this time a xenograft - a swine kidney was anastomosed in the elbow of a woman with a terminal kidney disease. This procedure, however, was not successful, and the patient died. ${ }^{2}$ From 1950 on, Murray et al., with a better knowledge of pharmacologic immunosuppression, successfully transplanted solid organs, which resulted in the rapid increase of transplantations over the years until today. ${ }^{3}$

The skin is an active element of the immune system, which can be observed by molecular, functional and anatomic similarities with the epithelial cells of the thymus, a recognizably immunologic organ. ${ }^{4}$ It is the biggest human organ, not only being responsible for the production of keratin, but also functioning as a barrier against external agents. The skin is also responsible for the production, in the keratinocytes, of substances similar to the thymic factors responsible for the maturation of lymphocytes $\mathrm{T}$, that, together with the Langerhans cell, a primordial cell in the antigen presentation, perpetuate the immune response. ${ }^{4,5}$

All these defense mechanisms are jeopardized by the chronic use of immunosuppressant drugs and also as a result of metabolic alterations because of the graft's malfunctioning, such as the increase of methyl guanidine secondary to uremia, leading to an inhibition of the lymphocyte function. ${ }^{5}$ A valid option for the treatment of chronic renal insufficiency, the kidney transplantation represented a revolution for this group of patients, who previously had only hemodialysis or peritoneal dialysis as options of treatment, although with higher rates of morbimortality and worsening in quality of life. The transplantations have come to change this situation. However, while the prolonged immunosuppression increased these patients' survival, it also had a direct influence on the immune defense mechanisms with consequent decrease of cellular immunity and increase of susceptibility to various dermatoses, especially those of infectious origin. ${ }^{4,5,6}$ Considering the scarcity of this type of study in the Brazilian scientific literature, the aim of this paper was to evaluate the frequency of dermatoses in kidney transplant recipients; to identify the socio-demographic characteristics of these patients through parameters like gender, age range, origin, clinical features in terms of transplantation time and chemotherapy regimens used; and to demonstrate a possible relationship between the most frequent dermatoses and the time elapsed from the kidney transplantation and the kind of immunosuppressant treatment.

\section{MATERIAL AND METHODS}

This is a cross-sectional study involving all kidney transplant recipients regularly assisted at the reference assistance in nephrology of the Distrito Federal (Hospital Regional da Asa Norte-HRAN- and Hospital de Base) in the period between March $1^{\text {st }} 2009$ - June $30^{\text {th }}$ 2010. The patients went to hospital with dermatological complaints and were then referred to the Dermatology ward of HRAN for diagnosis. For recording data a protocol of research was used containing the dependent (dermatoses) and the independent variables (socio demographic: gender, age range and origin; and clinical: time of kidney transplantation and chemotherapy regimens used). The limitation of the study was the small number of patients and the short time available for carrying out research. Informed consent was obtained from all individuals enrolled in the study. Statistical analyses were performed by software SPSS 16.0/Excel 2007 ; the Chi-square and Fisher Exact tests were applied, considering $\mathrm{p}<0.05 \%$ as statistically significant. The study was approved by the Ethics Committee ESCS/FEPECS/SES/DF.

\section{RESULTS}

In 53 kidney transplant recipients referred from the nephrology services, we have found a total of 100 dermatoses; and $43.4 \%$ of patients had two distinct dermatologic diagnoses; $39.6 \%$ had only one dermatosis, while $11.3 \%, 1.9 \%, 1.9 \%$ and $1.9 \%$ had, respectively, 3, 4, 5 and 6 different diagnoses. Regarding gender, $52.8 \%$ (28 cases) were male and $47.2 \%$ ( 25 cases) were female patients. Patients were aged between 22 and 69 , with mean and median ages 44 years, mode 34 years, and standard deviation 11 years (Table 1).

Most of the patients came from the towns neighboring Distrito Federal or from nearby cities from the states of Goias and Minas Gerais. As to the time elapsed after transplantation, $52.8 \%$ had been transplanted more than five years; $28.3 \%$, from one to five years; and $18.9 \%$, less than one year (Graph 1). Prednisone was the most commonly used immunosuppressant drug (83\% of cases), followed by mycophenolate mofetil (58.5\%), cyclosporine (50.9\%), azathioprine $(39.6 \%)$, tacrolimus $(24.5 \%)$ and sirolimus $(15.1 \%)$. The need for laboratory diagnosis, with anatomopathological examination of the injured skin, direct mycological examination and cultures, occurred in $69.8 \%$ of cases. In $30.2 \%$ of cases the diagnosis was essentially clinical. The main groups of der- 
TABLE 1: Distribution of socio-demographic and clinical characteristics of kidney transplant patients

\begin{tabular}{|c|c|c|c|c|c|}
\hline Variables & $\mathbf{n}$ & $\%$ & Variables & $\mathbf{n}$ & $\%$ \\
\hline \multicolumn{3}{|l|}{ Gender } & \multicolumn{3}{|l|}{ Fungal dermatoses } \\
\hline Male & 28 & 52.8 & Onychomycosis & 13 & 24.5 \\
\hline Female & 25 & 47.2 & Pityriasis versicolor & 5 & 9.4 \\
\hline \multicolumn{3}{|l|}{ Age range } & Pityrosporum folliculitis & 4 & 7.5 \\
\hline 20 - 29 years & 5 & 9.4 & Tinea cruris & 3 & 5.7 \\
\hline 30 - 39 years & 15 & 28.3 & Tinea pedis & 3 & 5.7 \\
\hline 40 - 49 years & 16 & 30.2 & Tinea manum & 1 & 1.9 \\
\hline 50 - 9 years & 12 & 22.6 & Toe-web intertrigo & 1 & 1.9 \\
\hline $60-69$ years & \multirow[t]{2}{*}{5} & \multirow[t]{2}{*}{9.4} & Angular cheilitis & 1 & 1.9 \\
\hline Origin & & & Tinea corporis & 1 & 1.9 \\
\hline Ceilândia/DF & 6 & 11.3 & Paronychia & 1 & 1.9 \\
\hline Recanto das Emas/DF & 5 & 9.4 & \multirow{2}{*}{\multicolumn{3}{|c|}{ Viral dermatoses }} \\
\hline Samambaia/DF & 4 & 7.5 & & & \\
\hline São Sebastião/DF & 4 & 7.5 & Viral warts & 14 & 26.4 \\
\hline Luziânia/GO & 3 & 5.7 & Herpes zoster & 4 & 7.5 \\
\hline Sobradinho/DF & 3 & 5.7 & Molluscum contagiosum & 3 & 5.7 \\
\hline Planaltina/DF & 3 & 5.7 & Herpes simplex & 3 & 5.7 \\
\hline Others & 25 & 47.2 & Condyloma acuminatum & 1 & 1.9 \\
\hline \multicolumn{3}{|l|}{ Time of kidney transplantation } & \multicolumn{3}{|c|}{ Pre-malignant and malignant dermatoses } \\
\hline Less than 1 year & 10 & 18.9 & Basal cell carcinoma & 6 & 11.3 \\
\hline $1-5$ years & 15 & 28.3 & Actinic keratoses & 5 & 9.4 \\
\hline Over 5 years & 28 & 52.8 & Squamous cell carcinoma & 3 & 5.7 \\
\hline \multicolumn{6}{|l|}{ Immunosuppressant drugs } \\
\hline Prednisone & 44 & 83.0 & Other dermatoses & & \\
\hline Mycophenolate mofetil & 31 & 58.5 & Melasma & 7 & 13.3 \\
\hline Cyclosporine & 27 & 50.9 & Acneiform eruption & 4 & 7.6 \\
\hline Azathioprine & 21 & 39.6 & Contact eczema & 2 & 3.8 \\
\hline Tacrolimus & 13 & 24.5 & Rosacea & 2 & 3.8 \\
\hline \multirow{2}{*}{ Sirolimus } & \multirow[t]{2}{*}{8} & \multirow[t]{2}{*}{15.1} & Stasis dermatitis & 1 & 1.9 \\
\hline & & & Asteatotic eczema & 1 & 1.9 \\
\hline \multicolumn{6}{|l|}{ Dermatoses } \\
\hline Fungal dermatoses & 23 & 43.4 & \multicolumn{3}{|l|}{ Bacterial dermatoses } \\
\hline Viral dermatoses & 21 & 39.6 & Furuncle & 2 & 3.8 \\
\hline Other dermatoses & 13 & 24.5 & Cellulitis & 1 & 1.9 \\
\hline Malignant dermatoses & 9 & 17.0 & & & \\
\hline Pre-malignant dermatoses & 5 & 9.4 & & & \\
\hline Bacterial dermatoses & 3 & 5.7 & & & \\
\hline
\end{tabular}

matoses observed in kidney transplant recipients were fungal $(43.4 \%)$, followed by viral dermatitis $(39.6 \%)$, other dermatoses $(24.5 \%)$, cutaneous neoplasms represented by squamous and basal cell carcinomas $(17 \%)$, pre-malignant dermatoses $(9.4 \%)$ and bacterial dermatoses (5.7\%) (Graph 2).

All 32 patients affected with fungal dermatoses presented superficial, rather than deep or systemic mycoses. Candidoses accounted for the most frequently found group of superficial mycosis $(22.6 \%$ of cases), followed by dermatophytoses $(18.9 \%)$ and der- matoses caused by Malassezia spp (17\%) (Graph 3). Regarding the diagnosis of onychomycoses, one patient did not undergo the examination and another presented a negative result in the mycological exam, even having a diagnosis of onychomycosis in the toenails. These patients did not return for laboratory examinations. Among the main agents of onychomycoses, Candida spp occurred in $13.2 \%$ and Trichophyton rubrum in 3.8\% of cases (Graph 4). The dermatoses caused by Malassezia spp were represented by pityriasis versicolor (five cases) and pityrosporum folliculitis 


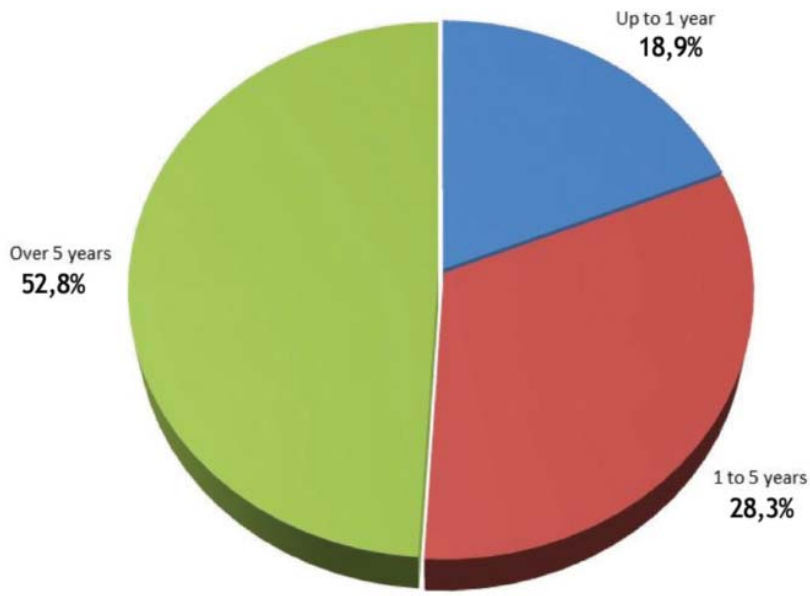

GRAPH 1: Time of renal transplantation in patients with dermatoses studied from March 2009 to June 2010

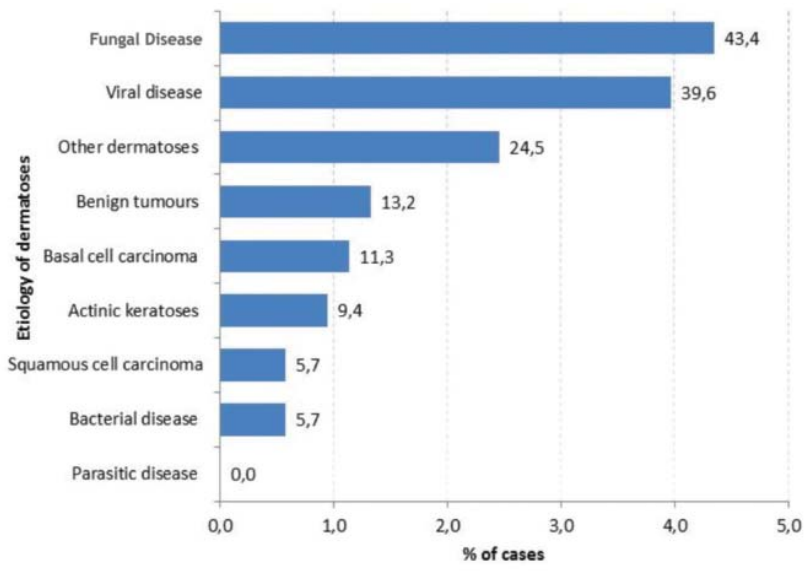

GRAPH 2: Groups of dermatoses observed in renal transplant patients studied from March 2009 to June 2010.

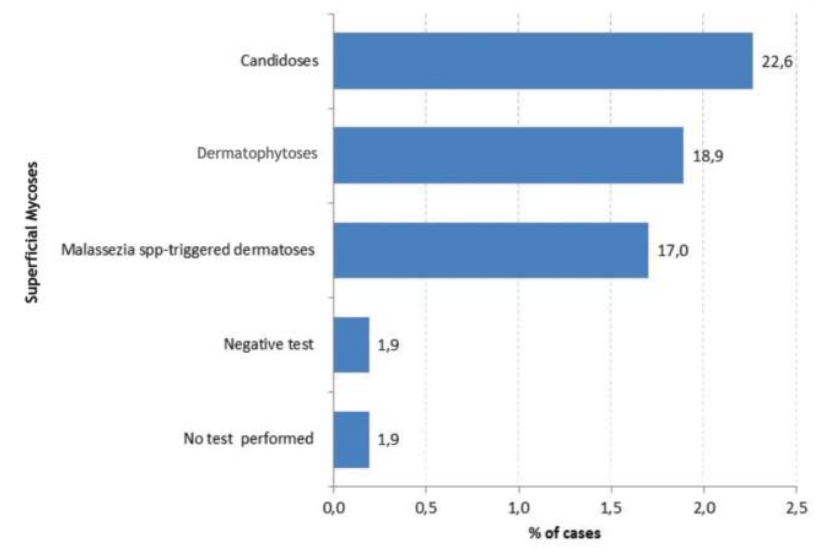

GRAPH 3: Groups of superficial mycoses observed in renal transplant patients studied from March 2009 to June 2010

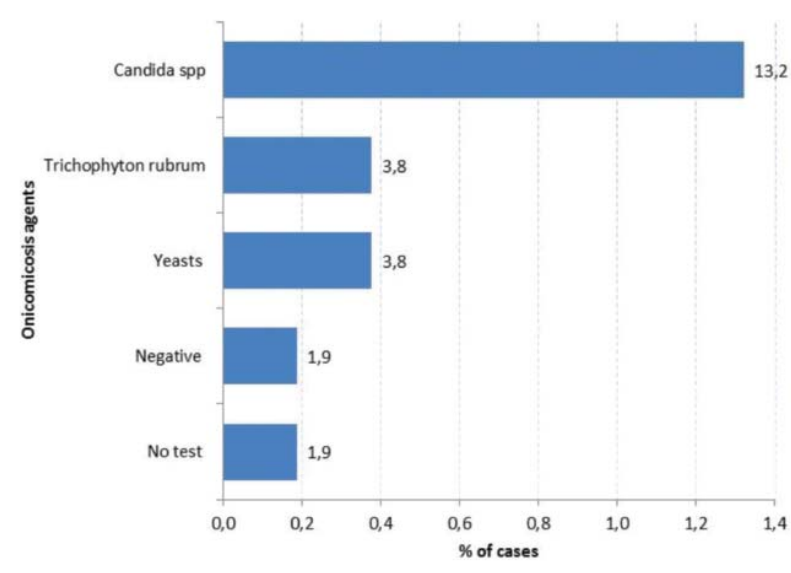

GrAPH 4: Etiologic agents of onychomycosis observed in renal transplant patients studied from March 2009 to June 2010

(four cases), $9.4 \%$ and $7.5 \%$ of cases, respectively. Only one case of toe-web intertrigo, paronychia and angular cheilitis occurred in each group, all of them having Candida $s p$ as etiology. Tinea pedis (three cases), cruris (three cases), manum (one case) and corporis (one case) were also observed.

The viral dermatoses were the second most frequently found group of dermatoses; viral warts occurred in $26.4 \%$ of cases, herpes zoster in $7.5 \%$; herpes simplex in $5.7 \%$; molluscum contagiosum in $5.7 \%$; and condyloma acuminatum in $1.9 \%$ (Graph 5).

It is important to highlight the occurrence of other groups of dermatoses, especially inflammatory diseases such as acneiform eruptions, rosacea, asteatotic eczema, contact eczema and stasis dermatitis. This group had a lower incidence when compared with other groups of dermatological diseases. It is also important to point out the high occurrence of

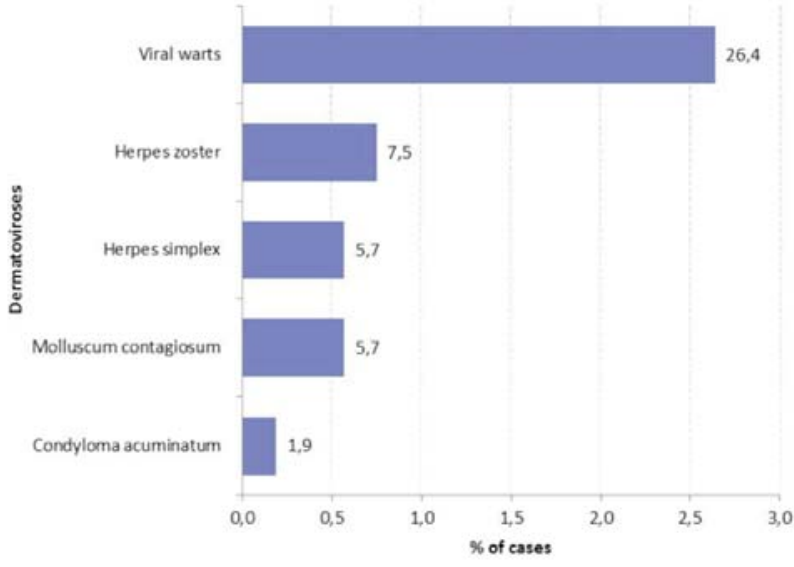

GrAPH 5: Dermatoviroses groups observed in kidney transplant patients studied from March 2009 to June 2010 
melasma in these patients (11.3\%), which reveals preoccupation with physical appearance and lack of care with sun protection.

With regard to pre-malignant and malignant neoplastic diseases, the basal cell carcinoma (BCC), the squamous cell carcinoma (SCC) and the actinic keratosis were seen in $11.3 \%, 5.7 \%$ and $9.4 \%$ of cases, respectively. The bacterial dermatoses occurred in $5,7 \%$ of patients, represented by two cases of furuncle and one case of cellulitis.

No statistically significant association was seen between the fungal and viral diseases and the time elapsed after kidney transplantation. Neither was statistically significant association seen between fungal and viral diseases and the use of the main immunosuppressant drugs like cyclosporine, azathioprine, mycophenolate mofetil, tacrolimus and sirolimus. Yet, there was statistically significant association between the use of prednisone and the occurrence of fungal dermatoses, according to the one-tailed Fisher Test ( $p$ $=0.034)$ (Table 2$)$.

TABLE 2: Statistically significant, according to the one-tailed Fisher's exact test $(p=0.034)$

\begin{tabular}{clllllll}
\hline & \multicolumn{9}{c}{ Prednisone } \\
\cline { 2 - 8 } Fungal disease & Yes & \multicolumn{3}{c}{ No } & \multicolumn{2}{c}{ Total } \\
\cline { 2 - 8 } & $\mathrm{n}$ & $\%$ & $\mathrm{n}$ & $\%$ & \multicolumn{2}{c}{$\mathrm{n}$} & $\%$ \\
\cline { 2 - 8 } Yes & 22 & 50,0 & 1 & 11.1 & 23 & 43.4 \\
No & 22 & 50,0 & 8 & 88.9 & 30 & 56.6 \\
Total & 44 & 100.0 & 9 & 100.0 & 53 & 100.0 \\
\hline
\end{tabular}

\section{DISCUSSION}

The cutaneous manifestations are frequent in kidney transplant recipients, and this is probably related to the use of the immunosuppressant drugs prescribed by the nephrologists after graft. ${ }^{4,5,67,8} \mathrm{We}$ have observed the multiplicity of dermatologic diagnosis, with a variety of dermatoses in a single patient. Two or more distinct diagnoses were observed in more than $50 \%$ of cases.

The prevalence of fungal infections in kidney transplant recipients observed in the literature ranges from $7 \%$ to $73.6 \%{ }^{9,10,11}$ In this study, similar rates have been observed. All cases of fungal dermatoses were superficial mycoses, without any cases of systemic or deep fungal infections. Yet, the literature states that skin lesions can be the first clinical finding of a systemic invasive fungal infection. ${ }^{5,6,12}$ We should then draw attention to early diagnosis and treatment in these cases.

In tropical climate countries like Brazil the literature records superficial mycoses in $48 \%$ to $85 \%$ of cutaneous infections, in compliance with our study. In temperate climate countries, the cutaneous infections observed in kidney transplant recipients are predominantly viral, with fungal dermatoses occurring in $7 \%$ to $15 \%$ of cases. ${ }^{5,13}$

Among the superficial mycoses, the pityriasis versicolor is the most frequently found in the literature, especially in the first year after transplantation, with rates ranging from $69.8 \%$ to $83.8 \%{ }^{6,12,14,15}$ These rates do not coincide with our findings, which were of $17 \%$, with candidoses predominating. Over $70 \%$ of our patients had been transplanted for more than one year, which could explain the results. The occurrence of pityriasis versicolor within the first year of graft is due to the use of high doses of immunosuppressant drugs in the post-transplantation period, leading to the accumulation of lipids in the skin and probably favoring the increase of this lipophilic yeast., ${ }^{5,12}$

Among the onychomycoses, Candida spp was the most observed etiological agent, followed by Trichophyton rubrum. These data differ from reports in the literature, which point Trichophyton rubrum and Trichophyton mentagrophytes as the prevalent agents involved. ${ }^{5,6,12,14}$ Montenegro et al. reported onychomycoses in their study, with the genus Candida prevailing, and highlighted the importance of advocating prophylactic methods in immunosuppressed patients and considering the proper early diagnosis and treatment. These injuries can be typical, but are often atypical.,12 Aspergillus spp, Candida spp, Malassezia spp are generally observed soon after transplantation .

Cryptococcosis usually occurs six months after transplantation. The incidence of the dermatophytoses increases as transplantation time elapses. Coccidioides immitis, Histoplasma capsulatum and Blastomyces spp can appear at any moment after transplantation..$^{12}$ All these data verified in the literature are of utmost importance for the dermatologist who will, thus, be able to predict the fungal dermatoses and the time they may appear in this special group of patients.

Viral infections occur almost exclusively by herpesvirus in the first years after transplantation, while the warts appear later; $85 \%$ of kidney transplant recipients report them five years after graft. ${ }^{6,16,17}$ In this study, although the viral warts were the second most prevalent group, no statistically significant relation was seen between the time elapsed after transplantation and their appearance. This may be due to the small number of participants in this study. Infections by human herpesvirus in transplant recipients were predominantly mucocutaneous lesions in the oropharynx or genital regions. ${ }^{17}$ Three cases of herpes simplex infection occurred, among which one patient presented multiple relapsing lesions in several sites, like lower limbs, gluteus and scalp (Figure 1). 


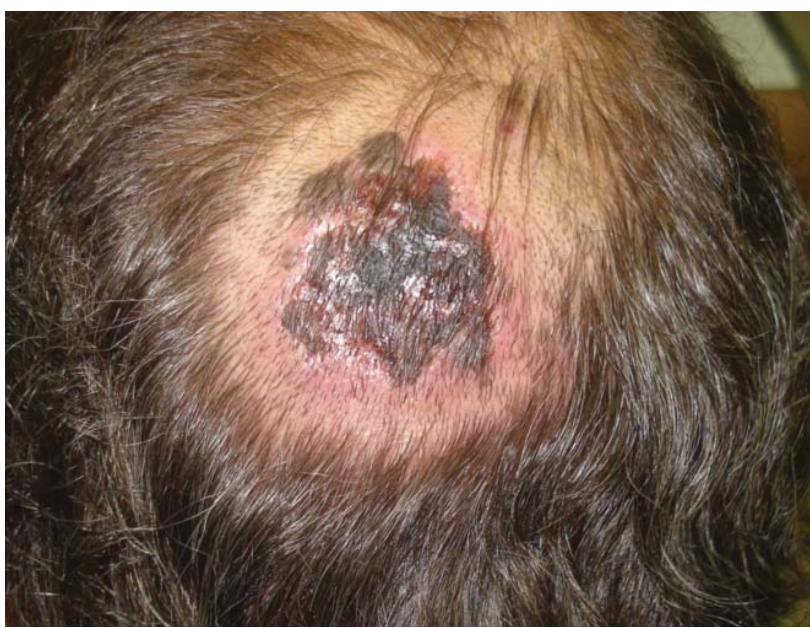

FIGURE 1: Herpetic lesions on the scalp of a renal transplant patient

The diagnosis of human papillomavirus (HPV) infection is also important since it may predispose the recipients to certain types of skin cancer, especially the squamous cell carcinoma (SCC). These patients pose a great challenge as they might never be totally free of the infection..$^{10,17,18}$ Kidney transplant recipients also have high risk of genital HPV infection; in our work, however, a low incidence of these cases was seen. Halpert et al. found cytological evidences of HPV infection in $22 \%$ of kidney-transplanted women compared with $2.5 \%$ of control immunocompetent patients paired by race, age range and age of first intercourse. ${ }^{19}$ In another study that compares the prevalence of HPV16 detected by PCR in 133 kidney transplant recipients and 145 controls, the prevalence of this serotype was demonstrated in $47 \%$ of individuals against $12.4 \%$ in the control group..$^{20}$ Molluscum contagiosum (MC) was also a rarely found viral dermatosis in the study; however, in those affected, the multiple lesions were difficult to treat. The extension of MC in transplant recipients is not as well recorded as other infections. ${ }^{17}$ In a study of skin disease with 145 transplanted children, MC occurred in $6.9 \%$ of patients, being the fourth most detected infection after viral warts, pityriasis versicolor and herpes simplex / herpes zoster. ${ }^{21}$

Non-melanoma skin cancer (NMSC), represented by squamous cell carcinoma (SCC) and by basal cell carcinoma (BCC), is responsible for $90 \%$ of all skin cancers in transplant recipients. The SCC seems to be the most common and aggressive. ${ }^{22,23}$ In our study, unlike the literature, BCC prevailed. Twenty years after transplantation, $40-50 \%$ of the Caucasian transplanted individuals in Western countries and 70-80\% of the Australian transplanted people developed at least one NMSC. In Dutch transplant recipients, the incidence of skin cancer is $0.2 \%$ and its incidence in the long term is $41 \%$. In Japanese transplant recipients, the skin cancers seem to be extremely rare. ${ }^{22,23,24,25,26}$ Most of the patients with NMSC in this study (six patients with BCC and three with SCC), had undergone the transplantation more than five years before, in compliance with the literature and reinforcing the increase of the incidence of the neoplasms as the graft time elapses .

Transplant recipients with skin type I-IV are in high risk of having SCC. This risk is 65-250 times higher when compared with the non-transplanted population. ${ }^{22,23}$ In our study, among the six patients with BCC, four were Caucasian and two were mulatto. The risk of having BCC is 10-16 times higher in transplanted people when compared with the nontransplanted population. The conclusion is that the risk of BCC occurring increases linearly whereas the risk of SCC increases exponentially. The relation SCC/BCC is 3:1 (inverse in the non-transplanted population). ${ }^{22,23}$ In our patients, this relation was 1:2, unlike the literature. A larger proportion of cases of $\mathrm{BCC}$ in relation to SCC had been previously reported in Mediterranean transplanted populations. Genetic antecedents of the transplant recipients in this region, sun exposure habits and phenotype characteristics could explain the increased incidence of BCC in this group of patients. ${ }^{11}$

The relative risk of SCC after transplantation is higher for males than for females, except for lip cancers. ${ }^{27}$ All SCC patients in this study were males. The severity of these tumors is linked to their quantity. About $30 \%$ to $50 \%$ of SCC patients also have BCC. ${ }^{28}$ Only one patient had multiple lesions caused by skin cancer, concomitant with SCC and BCC. According to a Scandinavian study, $25 \%$ of the patients who had SCC will have another lesion within 13 months, and $50 \%$ within 3.5 years. ${ }^{27}$ Liddington et al. reported an average interval of 15 months between the detection of the first and the second cancer, and 11 months between the second and the third one. ${ }^{29}$

SCC is associated with multiple warts, premalignant keratoses, Bowen Disease and keratoacanthoma. The appearance of a lesion can be deceiving since those that look like warts can be found, in the histological examination, to be an SCC, Bowen disease or keratoacanthoma. It is not always possible to distinguish between an SCC and a keratoacanthoma, even after histological examination. However, every keratoacanthoma in a transplanted person should be considered equivalent to an SCC. ${ }^{29,30}$ All the neoplastic and pre-neoplastic dermatoses in this study, including BCC, SCC, actinic keratosis and Bowen disease, were confirmed by histological assays. The actinic keratoses, in clinical aspects, resembled viral warts, thus the need for histological exam. 
$\mathrm{UV}$ radiation is the most important factor for the appearance of skin cancer, as its increased incidence occurs in countries with high sun exposure (for example, Australia). ${ }^{31}$ In this study, there was an expressive number of melasma cases, which demonstrates lack of sun protection and consequently a higher risk of cutaneous neoplasms. However, in the patients who presented melasma, no cases of skin cancer occurred.

\section{CONCLUSION}

In this study, infectious diseases, especially the fungal dermatoses, were prevalent in kidney transplant recipients. Viral dermatoses came second, from which $39.6 \%$ were viral warts. The immunosuppression, mainly through prednisone, favored the appearance of fungal lesions, confirmed by statistical findings. The results of this work lead us to highlight the importance of photo protection, as cutaneous neoplasms and some cases of melasma were reported, therefore making necessary the orientation of these transplant recipients. The results also reinforce the importance of dermatologic examinations, in addition to the need for periodic follow-up in all kidney transplant recipients, so as to provide early diagnosis and treatment of dermatoses and better quality of life for the patients. $\square$

\title{
REFERENCES
}

1. Nagy J. A note on the early history of renal transplantation: Emerich (Imre) Ullmann. Am J Nephrol. 1999;19:346-9.

2. Druml W. The beginning of organ transplantation: Emerich Ullmann (1861-1937). Wien Klin Wochenschr. 2002;114:128-37.

3. Tobin GR, Breidenbach WC 3rd, Ildstad ST, Marvin MM, Buell J, Ravindra KVF. The history of human composite tissue allotransplantation. Transplant Proc. 2009;41:466-71.

4. Mameri ACA, Delmaestro D, BouHabib JC. Manifestações cutâneas em transplantados renais- um estudo prospectivo. An Bras Dermatol. 1989;64:165-70.

5. Montenegro FF, Roselino AMF, Mazzocato TS, Maffei CML. Aspectos clínicos e micológicos de pele sã e lesada em transplantados renais. An Bras Dermatol. 1997;72:231-6

6. Vettorato G, Carvalho AVE, Lecompte SM, Trez EG, Garcia VD. Frequency of infectious dermatosis in 208 renal transplant recipients. An Bras Dermatol. 2003;78:283-8.

7. Pierezan CC, Vettorato G, Schwartz J, Gervini RL. Verucons scabies in a renal transplant recipient. An Bras Dermatol. 2000;75:31-4.

8. Zanol JDR, Carvalho AVE, Lecompte SM, Trez EG. Kaposi's Sarcoma in a renal transplant patient receiving Fk-506. An Bras Dermatol. 2002;77:707-710.

9. Bencini PL, Montaginino G, De Vecchi A, Tarantino A, Crosti C, Caputo R, Ponticelli C. Cutaneous Manifestation in Renal Transplant Recipients. Nephron. 1983:34:79-83.

10. Sandoval M, Ortiz M, Díaz C, Majerson D, Molgó M. Cutaneous Manifestations in Renal Transplant Recipients of Santiago, Chile. Transplant Proc. 2009;41:3752-4.

11. Formicone F, Fargnoli MC, Pisani F, Rascente M, Famulari A, Peris K. Cutaneous manifestations in Italian Kidney Transplant Recipients. Transplant Proc. 2005;37:2527-8.

12. Virgili A, Zampino MR, Mantovani L. Fungal skin infections in organ transplant recipients. Am J Clin Dermatol. 2002;03:19-35.

13. Prakash J, Singh S, Prashant GK, Kar B, Tripathi K, Singh PB. Mucocutaneous lesions in Transplant Recipient in a Tropical Country. Transplantation Proceedings. 2004;36:2162-4.

14. tAbel EA. Cutaneous manifestations of immunosuppression in organ transplant recipients. J Am Acad Dermatol. 1989;21:167-79.

15. Ghaninejad H, Ehsani AH, Ghiasi M, Noormohammadpour P, Najafi E, Naderi G, et al. Benign and malignant skin lesions in renal transplant recipients. Indian Journal Dermatol. 2009;54:247-50.

16. Bencini PL, Montaginino G, Sala F, De Vecchi A, Crosti C, Tarantino A. Cutaneous Lesions in 67 ciclosporin-treated renal transplant recipients. Dermatologica. 1986;172:24-30.

17. Tan HH, Goh CL. Viral Infections Affecting the Skin in Organ Transplant RecipientsEpidemiology and Current Management Strategies. Am J Clin Dermatol. 2006;7:13-29.

18. Hepburn DJ, Divakar D, Bailey RR, Macdonald KJ. Cutaneous manifestation of renal transplantation in a New Zealand population. N Z Med J. 1994;107:497-9.

19. Halpert R, Fruchter RG, Sedlis A, Butt K, Boyce JG, et al. Human papillomavirus and lower genital neoplasia in renal transplant patients. Obstet Gynecol. 1986; 68: 251-8.

20. Ogunbiyi OA, Scholefield JH, Raftery AT, Smith JH, Duffy S, Sharp F, et al. Prevalence of anal human papillomavirus infection and intraepithelial neoplasia in renal allograft recipients. Br J Surg. 1994;81:365-7.

21. Euvrard S, Kanitakis J, Cochat P, Cambazard F, Claudy A. Skin diseases in children with organ transplants. J Am Acad Dermatol. 2001;44: 932-4.

22. Euvrard S, Kanitakis J, Claudy A. Skin cancers after organ transplantation. N Engl J Med. 2003;348:1681-91.

23. Ho WL, Murphy GM. Update on the pathogenesis of post-transplant skin cancer in renal transplant recipients. Br J Dermatol. 2008;158:217-24

24. Kanitakis K, Alhaj-Ibrahim L, Euvrard S, Claudy A. Basal cell carcinomas developing in solid organ transplant recipients- clinicopathologic study of 176 cases. Arch Dermatol. 2003;139:1133-7.

25. Moloney FJ, Almarzouqi E, O'Kelly P, Conlon P, Murphy GM. Sunscreen Use before and after transplantation and assessment of risk factors associated with skin cancer development in renal transplant recipients. Arch Dermatol. 2005;141:978-82.

26. Yayli S, Akyazi H, Bahadir S,I Alpay K, Çobanoglu Ü. Coexistence of basal cell carcinomas and multiple sebaceous gland hyperplasias in a cyclosporine (ciclosporin)treated renal transplant recipient. Am J Clin Dermatol. 2010;11:59-62.

27. Lindelöf B, Sigurgeirsson B, Gäbel H, Stern RS. Incidence of skin cancer in 5356 patients following organ transplantation. Br J Dermatol. 2000;143:513-9.

28. Euvrard S, Kanitakis J, Pouteil-Noble C, Dureau G, Touraine JL, Faure M, et al Comparative epidemiologic study of premalignant and malignant epithelial cutaneous lesions developing after kidney and heart transplantation. J Am Acad Dermatol. 1995;33:222-9.

29. Liddington M, Richardson AJ, Higgins RM, Endre ZH, Venning VA, Murie JA, et al. Skin cancer in renal transplant recipients. Br J Surg. 1989;76:1002-5.

30. Cooper SM, Wojnarowska F. The accuracy of clinical diagnosis of suspected premalignant and malignant skin lesions in renal transplant recipients. Clin Exp Dermatol. 2002;27:436-8

31. Bouwes Bavinck JN, Hardie DR, Green A, Cutmore S, MacNaught A, O'Sullivan B, et al. The risk of skin cancer in renal transplant recipients in Queensland, Australia: a follow-up study. Transplantation. 1996;61:715-21.

\author{
MAILING ADDRESS: \\ Alexandre Moretti de Lima \\ Rua Dr. Arthur Jorge, 2165 - Monte Castelo \\ 79010-210 - Campo Grande - MS \\ Brazil \\ E-mail:morettilima@yahoo.com.br
}

How to cite this article: Lima AM, Rocha SP, Reis Filho EGM, Eid DRM, Reis CMS. Study of dermatosis in kidney transplant patients. An Bras Dermatol. 2013;88(3)361-7. 